but, in its applications, almost everybody's subjectand especially now that it has penetrated down to the molecular level, to the new underworlds of visual crystallography, visual chemistry and the like.

To-day we are recapturing with visible molecules the historic thrill that must have been experienced by Leeuwenhoek when first he perceived his "little animals". His creatures have become the monsters of our underworld, and indeed they have grown so big that we are now struggling with the problem of how best to break them down into authentic components sufficiently small for electron microscopy.

It is a pity to have to find fault in any way with this worthy effort of Dr. Wyckoff's, or rather the outcome of it; but it has to be admitted that the reproductions of his electron micrographs are scarcely as good as is required to realize to the full the inspirational value of the text. There are 202 illustrations, which means that the work is also by way of being an atlas of electron microscopy, with all the responsibility that implies. The non-specialist reader will probably judge the pictures excellent, and so they are as text-book reproductions usually go ; but those who are acquainted with the great beauty and detail of some of the originals are bound to heave a sigh, and even those who are not will be puzzled sometimes to pick out what is being described. Undoubtedly it is a matter of expense, since $£ 2$ is already a substantial price for what is, after all, not a very fat book.

There is an extensive bibliography, arranged chapter by chapter. There are not many printer's errors, but a peculiar spelling aberration (also in the index) is "comma" for the optical aberration 'coma". Occasionally, as in the legend to Fig. VIII, 1 ("Chick embryo cultured elementary bodies of a strain of psittacosis virus, etc."), there are constructions to which some of us in Britain still do not take very kindly; but that is a question of taste, or perhaps only conservatism.

\section{W. T. Astbury}

\section{OUTLINE OF MATERIALIST PHILOSOPHY}

Philosophy for the Future

The Quest of Modern Materialism. Edited by Roy Wood Sellars, V. J. McGill and Marvin Farber. Pp. xiv +657. (New York: The Macmillan Comapany; London: Macmillan and Co., Ltd., 1949.) 37s. 6d. net.

THE general view of the authors of this ambitious

and competent work is that the power and capacity of a materialist philosophy have never been satisfactorily assessed, especially in relation to contemporary and future noeds. Even without necessarily endorsing every aspect of this outlook, it is natural to extend a welcome to this book, and to see in it a solid contribution to its own particular branch of knowledge. The impression it gives - not so much in detail as in the manner of its broad sweep-is of a co-operative effort specifically designed for an American public, and one likely to win attention and hold it in the characteristic philosophical 'climate' of the United States.

With an array of some thirty contributors to consider, it is evidently unprofitable to select passages here and there for comment; better, it would seem, to attempt some assessment of the pattern as they have woven it. Thus a series of historical chapters comes first, followed by a set dealing in detail with outstanding examples of the materialist position to-day; and lastly, and perhaps the most valuable, several articles descriptive of divergent systems of thought, so divergent in fact as, for example, logical empiricism and Neo-Thomism-and all this with a common aim, kept in reasonably sharp focus.

A good feature is the way in which definite points are allowed to emerge. An illustration of this is the fervent desire of the Vienna Circle and their successors to banish metaphysics, and to make everything depend upon criteria of verifiability ; as is well and truly remarked, rejection or denial of something is utterly different from 'really' getting rid of ittheories of Being are not liquidated so easily as that.

To some minds, maybe, these pages will raise more questions than they answer; it is probably well that they should. Philosophy, after all, is quite as intent upon realizing problems as in solving them.

F. I. G. RaWLINS

\section{WILD ANIMALS IN BRITAIN}

\section{Wild Animals in Britain}

Mammals, Reptiles and Amphibians. By Oliver G. Pike. Pp. xii $+231+8$ plates. (London: Macmillan and Co., Ltd., 1950.) 18s. net.

$T$ HE mammals of the British Isles do not make a long list ; but it is a highly interesting one. On this list are found many species and subspecies that show differentiation and peculiarities due to isolation on islands. We appear to have new species in the making, this evolution proceeding under our eyes.

"Wild Animals in Britain", by Mr. O. G. Pike, another volume of the Macmillan series that deals with the British fauna and flora, covers the mammals, reptiles and amphibians and their island races.

Mr. Pike is well qualified to write on this subject, having a wide experience of British wild life, and he does so lucidly and entertainingly, giving much information that will be helpful to those interested in this branch of our fauna.

The reviewer, having a special interest in rodents, would have liked more space devoted to such small mammals as the unique Skomer vole, Clethrionomys skomerensis, found only on the six hundred or so acres of rocky island off the Pembrokeshire coast; but this book is a balanced survey, not an exhaustive account of any particular creature, and it admirably fulfils its purpose.

We must regret that it was not possible to include some account of certain domestic or semi-domestic animals, for example, the so-called wild white cattle, and the Chillingham herd of them in particular. These cattle are of considerable interest, being a perpetuation of a primitive type once no doubt plentiful in these islands.

But such remarks are ungrateful where so much has been given the reader, and given so charmingly.

The illustrations consist of colour plates, being reproductions of sketches, including the frontispiece from a painting by $\mathrm{Mr}$. William Reeves, and a number of excellent photographs. A striking snapshot is that of a mountain hare in its form in a snowdrift by the late G. B. Kearey, and striking, too, is the photograph of a wood mouse by Dr. M. S. Wood. Frances PitT 